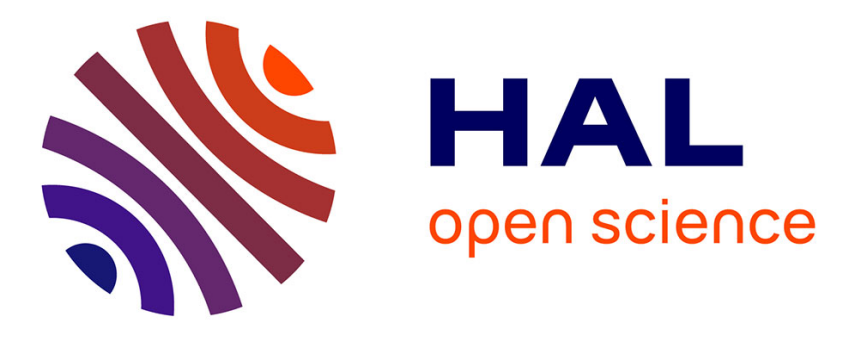

\title{
Electro Fenton removal of clopyralid in soil washing effluents
}

\author{
María Belén Carboneras Contreras, Florence Fourcade, Aymen Assadi, \\ Abdeltif Amrane, Francisco Jesus Fernandez-Morales
}

\section{- To cite this version:}

María Belén Carboneras Contreras, Florence Fourcade, Aymen Assadi, Abdeltif Amrane, Francisco Jesus Fernandez-Morales. Electro Fenton removal of clopyralid in soil washing effluents. Chemosphere, 2019, 237, pp.124447. 10.1016/j.chemosphere.2019.124447 . hal-02280865

\section{HAL Id: hal-02280865 \\ https://hal-univ-rennes1.archives-ouvertes.fr/hal-02280865}

Submitted on 16 Dec 2019

HAL is a multi-disciplinary open access archive for the deposit and dissemination of scientific research documents, whether they are published or not. The documents may come from teaching and research institutions in France or abroad, or from public or private research centers.
L'archive ouverte pluridisciplinaire HAL, est destinée au dépôt et à la diffusion de documents scientifiques de niveau recherche, publiés ou non, émanant des établissements d'enseignement et de recherche français ou étrangers, des laboratoires publics ou privés. 


\section{Electro Fenton removal of clopyralid in soil washing effluents}

3 María Belén Carboneras Contreras ${ }^{1,2}$, Florence Fourcade ${ }^{2 *}$, Aymen Assadi², Abdeltif

$4 \quad$ Amrane $^{2}$, Francisco Jesus Fernandez-Morales ${ }^{1 *}$

6 (1) Chemical Engineering Department. Research Institute for Chemical and

7 Environmental Technology (ITQUIMA). University of Castilla- La Mancha, 13071,

8 Ciudad Real, Spain

9 (2) Univ Rennes, Ecole Nationale Supérieure de Chimie de Rennes, CNRS, UMR 6226,

F-35000 Rennes, France

*Corresponding authors:

Francisco Jesus Fernández Morales

University of Castilla-La Mancha, ITQUIMA, Chemical Engineering Dept., Avda. Camilo José Cela S/N 13071, Ciudad Real, Spain

Tel: 0034926295300 (ext. 6350), Fax: 0034926295242

E-mail: fcojesus.fmorales@uclm.es

Orcid iD: 0000-0003-0389-6247

\section{Florence Fourcade}

University of Rennes, Ecole Nationale Supérieure de Chimie de Rennes, CNRS, UMR 6226, F-35000 Rennes, France

E-mail: florence.fourcade@ univ-rennes1.fr 


\section{Abstract}

44 Keywords: Electro-Fenton; clopyralid; groundwater; soil washing effluent;

The removal of a commercial herbicide, based on clopyralid, by means of Electro-Fenton (EF) was studied using a soil washing effluent obtained using synthetic ground water as washing fluid. From the results, it was observed that the degradation and mineralization yields of clopyralid were high, even without the addition of supporting electrolyte. The groundwater could be then used as a sustainable supporting electrolyte. The influence of the minerals constituents, the current and the ferrous ions regeneration was evaluated. The highest hydrogen peroxide production was achieved working at $200 \mathrm{~mA}$ but regeneration of ferrous ions was not efficient at this current. Iodide ions were one of the main responsible in the EF efficiency decrease due to their reaction with the produced hydrogen peroxide. Electrochemical study proved that clopyralid was not electroactive and that its degradation was mainly due to radical oxidation. Long duration electrolysis carried out at $200 \mathrm{~mA}$ in groundwater provided an improvement of the solution biodegradability after $480 \mathrm{~min}$ that can be linked to a significant increase in the carboxylic acids production. These results support the feasibility of applying an EF process in order to carry out a subsequent biological mineralization. 


\section{INTRODUCTION}

The pollution related to the use and production of pesticides is an issue which not only has impact on the environment but also concerns human beings and wildlife. The application of pesticides is an essential tool for the correct development of crops, however it became a serious problem during the green revolution, increasing the loss of soil fertility, the soil acidification, the nitrate leaching, the resistance of weed species and the loss of biodiversity (Tilman et al., 2002; Verma et al., 2013; Verma et al., 2014). Additionally, according to the literature (Pimentel and Levitan, 1986), less than $0.1 \%$ of pesticides applied for pest control reach their target pests. It means that more than $99.9 \%$ of pesticides move into the environment, polluting water, soil and air. Water pollution by pesticides is a widespread problem. Several pesticides haven been detected in surface and groundwater, as it has been described by a great number of research studies (Bortleson and Davis, 1997; Aydin et al., 2018; Xie et al., 2019). Moreover, human health is significantly affected by this kind of pollution, producing, among other problems, fertility diseases (Cano-Sancho et al., 2019).

The removal of organic pollutants from waters has been studied during years and it is a topic which can be faced by using different technologies, from the adsorption of the pollutants on carbon materials (Liu et al., 2018) to the use of microorganisms to degrade the organic compounds (De Lucas et al., 2007; Garcia-Becerra and Ortiz, 2018; Gaur et al., 2018; Kumar et al., 2018). One of the most effective technologies to remove organic molecules from water is the Advanced Oxidation Process (AOP). They are defined as processes which involve the generation of highly reactive oxidizing species able to attack and degrade organic substances. This concept was established in the 1980s (Glaze, 1987; Huang et al., 1993). The AOP processes have demonstrated good efficiencies treating 
71 relatively low volumes of effluents at high concentrations. For this reason, they can be

72 used after a concentration step such as membrane separation or adsorption processes

73 (Pérez et al., 2010; Urtiaga et al., 2013; Wang et al., 2014; Liang et al., 2016; Bouaziz et

74 al., 2017; Aboudalle et al., 2018a). One class of AOPs that is gaining attention over the

75 last two decades are the electrochemical advanced oxidation processes (EAOPs)

76 (Comninellis et al., 2008; Barrera-Díaz et al., 2014; Chaplin, 2014; Moreira et al., 2017).

77 The main advantages of the EAOPs versus traditional AOPs are that this kind of

78 technology is able to manage a wide range of pollutants and concentrations, can in situ

79 generate $\mathrm{H}_{2} \mathrm{O}_{2}$, operates at mild conditions and can be easily scalable, amongst others.

80 Additionally, this technology provides some upsides for the prevention and remediation

81 of pollution problems because the electron is a non-polluting reagent (Sirés et al., 2014).

82 Nevertheless, EAOPs have associated important downsides such as the electrical costs

83 related to the energy supply and the consumption of chemicals as supporting electrolyte

84 (Oller et al., 2011; Sirés et al., 2014). In order to reduce the costs of the EAOP processes,

85 they can be coupled with cheap treatments such as the bioprocesses. The order in which

86 the EAOP and the bioprocess are combined attends to different factors such as the

87 biodegradability/toxicity of the effluents, the nature of the pollutant and the existence of acclimatized microbial cultures able to degrade the target pollutant amongst others (Oller et al., 2011; Ganzenko et al., 2014). 
91 Electro-Fenton (EF) process is considered one of the most efficient EAOPs processes.

92 The EF process is based on the electrogeneration of $\mathrm{H}_{2} \mathrm{O}_{2}$ at the cathode by reducing the

93 fed dissolved oxygen. The addition of an iron catalyst and an acid $\mathrm{pH}$ are necessary

94 conditions to produce oxidant $^{\bullet} \mathrm{OH}$ in the liquid bulk (Brillas et al., 2009; Barrera-Díaz et

95 al., 2014; Aboudalle et al., 2018a). Fenton`s reaction involves $\mathrm{H}_{2} \mathrm{O}_{2}$ and ferrous iron to 96 form $^{\bullet} \mathrm{OH}$ Eq. (1).

$97 \mathrm{H}_{2} \mathrm{O}_{2}+\mathrm{Fe}^{2+} \rightarrow \mathrm{Fe}^{3+}+\mathrm{OH}^{-}+{ }^{\bullet} \mathrm{OH}$

Electrochemical processes are usually characterized by the requirement of a supporting electrolyte, mineral salts which provide to the solution enough conductivity in order to decrease the cell voltage. However, the addition of mineral salts attained one important drawback, because in spite of improving the conductivity, it increases the pollution of the water (Belen Carboneras et al., 2018). Because of that, novel solutions must be reached.

In this context, this study focuses on the examination of the main parameters influencing the clopyralid removal and mineralization by means of the EF process. Moreover, a study of the influence of the operational variables over the enhancement of the biodegradability of the effluent caused by the EF process was carried out.

The EF clopyralid oxidation was implemented with and without the addition of any supporting electrolyte. To do that, a synthetic groundwater solution was used as soil washing fluid to enhance the conductivity, taking the advantage of this sustainable and non-polluting natural resource.

\section{MATERIALS AND METHODS}

\subsection{Chemicals and soil washing effluents}


114 In this work, the selected target pollutant was clopyralid. It was used in its commercial 115 formulation, Lontrel ${ }^{\circledR} 72(72 \%$ w/w), and was supplied by Dow AgroSciences. The 116 polluted effluents used in this research were synthetic soil washing effluents. The soil 117 washing fluid used to extract the pollutant from the soil was groundwater. According to 118 the composition and concentration of typical groundwater and the results described in the 119 literature (Minerales, 1985; Chair et al., 2017a; 2017b), the synthetic effluent presented the following concentrations: $\mathrm{Na}_{2} \mathrm{SO}_{4} 50 \mathrm{mM} ; \mathrm{MgSO}_{4} 7 \mathrm{H}_{2} \mathrm{O} 5.54 \mathrm{mM} ; \mathrm{NaCl} 2.25 \mathrm{mM}$; $\mathrm{NaNO}_{3} 1.53 \mathrm{mM}$; KI $0.15 \mathrm{mM} ; \mathrm{CaCO}_{3} 12.47 \mathrm{mM}$. $\mathrm{FeSO}_{4} \cdot 7 \mathrm{H}_{2} \mathrm{O}$ (purity 99\%), $\mathrm{Na}_{2} \mathrm{SO}_{4}$ and the rest of the chemicals used in this work were purchased from Acros Organics (Thermo Fisher Scientific, Geel, Belgium).

In the literature, it has been described that the optimum $\mathrm{pH}$ to carry out the EF process is 3 (Diagne et al., 2007). Because of that, the $\mathrm{pH}$ of the wastewater was adjusted to 3 before the experiments by adding analytical grade sulfuric acid $\mathrm{H}_{2} \mathrm{SO}_{4}$ purchased form Acros Organics. All the solutions were prepared using Ultrapure water (Millipore Elga).

\subsection{Electrochemical Apparatus and Procedures}

The electrochemical reactor consisted of a batch undivided cylindrical glass compartment with a volume of $800 \mathrm{~mL}$. The main components of the electrochemical cell were a cylindrical platinum anode $\left(32 \mathrm{~cm}^{2}\right)$, which was placed at the centre of the reactor and a tri-dimensional piece of carbon felt of $112 \mathrm{~cm}^{2}$ of geometrical area (Le Carbone Loraine RVG 4000 Mersen, Paris la Défense, France), which acted as cathode. The carbon felt electrode surrounded the platinum anode so as to get a good potential distribution. The main carbon felt characteristics were $35.3 \mathrm{~m}^{2} \mathrm{~g}^{-1}$ of specific area, $500 \mathrm{~g} \mathrm{~m}^{-2}$ of area weight, thickness of $0.4 \mathrm{~cm}$ and $95 \%$ of porosity). Before starting the electrolysis, compressed air was bubbled into the solution during $15 \mathrm{~min}$ in order to provide the solution with an 
appropriated $\mathrm{O}_{2}$ concentration. The experiments were carried out in duplicate, at $20{ }^{\circ} \mathrm{C}$ and galvanostatic conditions. The current was applied using a DC power supply (Metrix, model AX 322-Chauvin Arnoux Group, Paris, France). Just before the beginning of the EF reactions the catalytic $\mathrm{Fe}^{2+}$ was added into the reaction bulk as $\mathrm{FeSO}_{4} \cdot 7 \mathrm{H}_{2} \mathrm{O}$. The $\mathrm{Fe}^{2+}$ concentrations studied were $0.1,0.5,1,2$ and $5 \mathrm{mM}$.

In order to select the optimal operating conditions in terms of clopyralid degradation and mineralization, several experiments were made changing one of the main parameters influencing the EF process, the current applied. In the literature it has been described that the current governs the formation of $\mathrm{H}_{2} \mathrm{O}_{2}$, the regeneration of ferrous iron and therefore the production of hydroxyl radicals (Oturan et al., 2008; Özcan et al., 2009; Feng et al., 2014; Aboudalle et al., 2018b).

\subsection{Analytical procedure}

\subsubsection{High performance liquid chromatography (HPLC)}

Clopyralid concentration was measured by HPLC using a Waters 996 system equipped with a Waters 996 PDA (Photodiode Array Detector) and Waters 600LCD Pump. The column was a Waters C-18 (4.6 mm x $250 \mathrm{~mm}$ x $5 \mu \mathrm{m}$ ). Acetonitrile (purity 99.9\%) (HPLC grade) was purchased from Sigma Aldrich (Saint Quentin Fallavier, France). The mobile phase was a mixture of acetonitrile/ultra-pure water $(20 / 80 \mathrm{v} / \mathrm{v})$ with $0.1 \%$ of formic acid. The flow rate was $1 \mathrm{~mL} \mathrm{~min}^{-1}$ and the herbicide was detected at $280 \mathrm{~nm}$.

\subsubsection{Total organic carbon (TOC)}

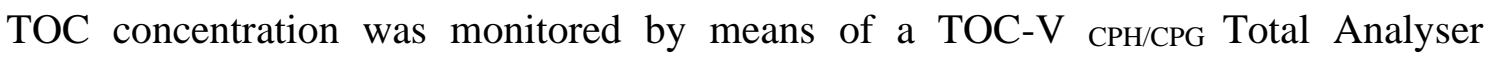
Schimadzu. Organic Carbon compounds were combusted and converted to carbon dioxide; then it was detected by a Non-Dispersive Infra-Red (NDIR) Detector. 


\subsubsection{Ion chromatography (IC)}

166

167

The carboxylic acids generated during the electrolysis were identified and quantified by a DIONEX DX120 ion chromatography. The chromatograph was equipped with a conductivity detector, using an anion exchange column AS19 (4 mm x $250 \mathrm{~mm}$ ) as the stationary phase, and solutions of $\mathrm{KOH}$ in water, prepared from $\mathrm{KOH}(12 \mathrm{M})$, as the mobile phase. The analysis were carried out using a gradient elution mode, starting with $10 \mathrm{mM} \mathrm{KOH}$ during $10 \mathrm{~min}$ and then increasing linearly to $45 \mathrm{mM}$ from 10 to $25 \mathrm{~min}$. Finally, from 25 to 35 min the concentration of $\mathrm{KOH}$ was $45 \mathrm{mM}$. The flow rate was set at $1 \mathrm{~mL} \mathrm{~min}{ }^{-1}$.

\subsubsection{Ferrous ions and $\mathrm{H}_{2} \mathrm{O}_{2}$ concentrations}

The ferrous ions concentration in the reactor was measured by means of a colorimetric principle, according to the Phenanthroline Method NF 90-017 (AFNOR, 1982). The concentration of $\mathrm{H}_{2} \mathrm{O}_{2}$ was determined by the potassium titanium (IV) oxalate method according to standard DIN 38 409, part 15, DEV-18 (Eisenberg, 1943).

\subsubsection{Chemical oxygen demand (COD) measurements}

CSB Nanocolor ${ }^{\circledR}$ tests were employed to analyse the COD of the samples. They were supplied by Macherery-Nagel (Düren, Germany).

\subsubsection{Biochemical oxygen demand $\left(\mathrm{BOD}_{5}\right)$ measurements}

In order to evaluate the influence of the EF process on the biodegradability of the soil washing effluents, $\mathrm{BOD}_{5}$ test were carried out using Oxitop ISA technology (from WTW, Alés, France). The tests were performed under the normalised conditions; $5 \mathrm{~d}$ at $20{ }^{\circ} \mathrm{C}$. 
Before the test, it was necessary to adjust the $\mathrm{pH}$ of all the samples at 7 by adding $\mathrm{NaOH}$.

190

191

192

193

194

195

196

197

198

199

200

201

202

203

204

205

206

207

208

209

210

211

212

The innoculum required to perform the analyses was collected from the municipal wastewater treatment plant (Rennes Beaurade, France). For inoculation of the bottles, an initial biomass concentration of $0.05 \mathrm{~g} \mathrm{~L}^{-1}$ was necessary. The following trace mineral were used to ensure the nutrients availability along the $\mathrm{BOD}_{5}$ tests $\left(\mathrm{g} \mathrm{L}^{-1}\right): \mathrm{MgSO}_{4} \cdot 7 \mathrm{H}_{2} \mathrm{O}$, 22.5; $\mathrm{CaCl}_{2}, 27.5 ; \mathrm{FeCl}_{3}, 0.15 ; \mathrm{NH}_{4} \mathrm{Cl}, 2.0 ; \mathrm{Na}_{2} \mathrm{HPO}_{4}, 6.80 ; \mathrm{KH}_{2} \mathrm{PO}_{4}, 2.80$.

To check the viability of the seed used as inoculum, a control test containing glutamic acid (150 $\left.\mathrm{mg} \mathrm{L}^{-1}\right)$ and glucose (150 $\left.\mathrm{mg} \mathrm{L}^{-1}\right)$ was carried out. Additionally, a blank test, in absence of carbon source, was performed in order to determine the endogenous oxygen consumption.

\subsubsection{Electrochemical analysis}

Voltammograms were obtained in a conventional three-electrodes cell with a scan rate of $100 \mathrm{mV} \mathrm{s}^{-1}$ using a BioLogic SP-150 potentiostat recorded to EC-Lab V10.36 software. As working electrode both, platinum and vitreous carbon, were tested. The platinum electrode $\left(3.14 \mathrm{~mm}^{2}\right)$ was used to characterize the anodic oxidation processes while the carbonous electrode $\left(7.07 \mathrm{~mm}^{2}\right)$ was used to study the cathodic reduction processes. In both cases, a Pt wire was used as the counter electrode and all the electrode potentials were measured with respect to a saturated calomel electrode (SCE) located near to the working electrode. Experiments were performed at ambient temperature under nitrogen atmosphere to avoid dissolved oxygen.

\section{RESULTS AND DISCUSSION}

\subsection{Effect of the mineral salts contained in the groundwater on the EF experiments}


213 Considering the composition of the soil washing solution, it must be highlighted that from

214 a thermodynamic point of view, redox reaction between the constituents cannot occur.

215 From Fig. 1, it can be seen that the composition of the supporting electrolyte directly 216 affected the clopyralid degradation and mineralization. As previously stated, the use of 217 groundwater could be a sustainable option for soil washing processes. In order to check 218 the influence of the different mineral salts, a set of experiments were carried out. To do 219 these experiments, 7 different electrolyte solutions were used. The first electrolyte 220 solution contained all of the components of the synthetic groundwater (Chair et al., 221 2017b). As a reference, a tests containing the typical electrolyte solution, $50 \mathrm{mM} \mathrm{Na}_{2} \mathrm{SO}_{4}$, 222 was carried out. Finally, with the aim to study the individual contribution of the minerals 223 contained in the synthetic ground water, 5 extra electrolyte solutions were prepared. 224 These electrolytes were based on the typical supporting electrolyte, $50 \mathrm{mM} \mathrm{Na}_{2} \mathrm{SO}_{4}$, but including in each case one of the minerals contained in the groundwater. The reaction conditions were $0.1 \mathrm{mM}$ of $\mathrm{Fe}^{2+}, 50$ and $100 \mathrm{~mA}$ of current. These operational conditions were identified as the optimum ones in a previous work carried out when operating with a similar set-up (Dalle et al., 2017). The current intensities studied yield very similar results. Because of that, only the results obtained at $50 \mathrm{~mA}$ are presented in Fig. 1. 

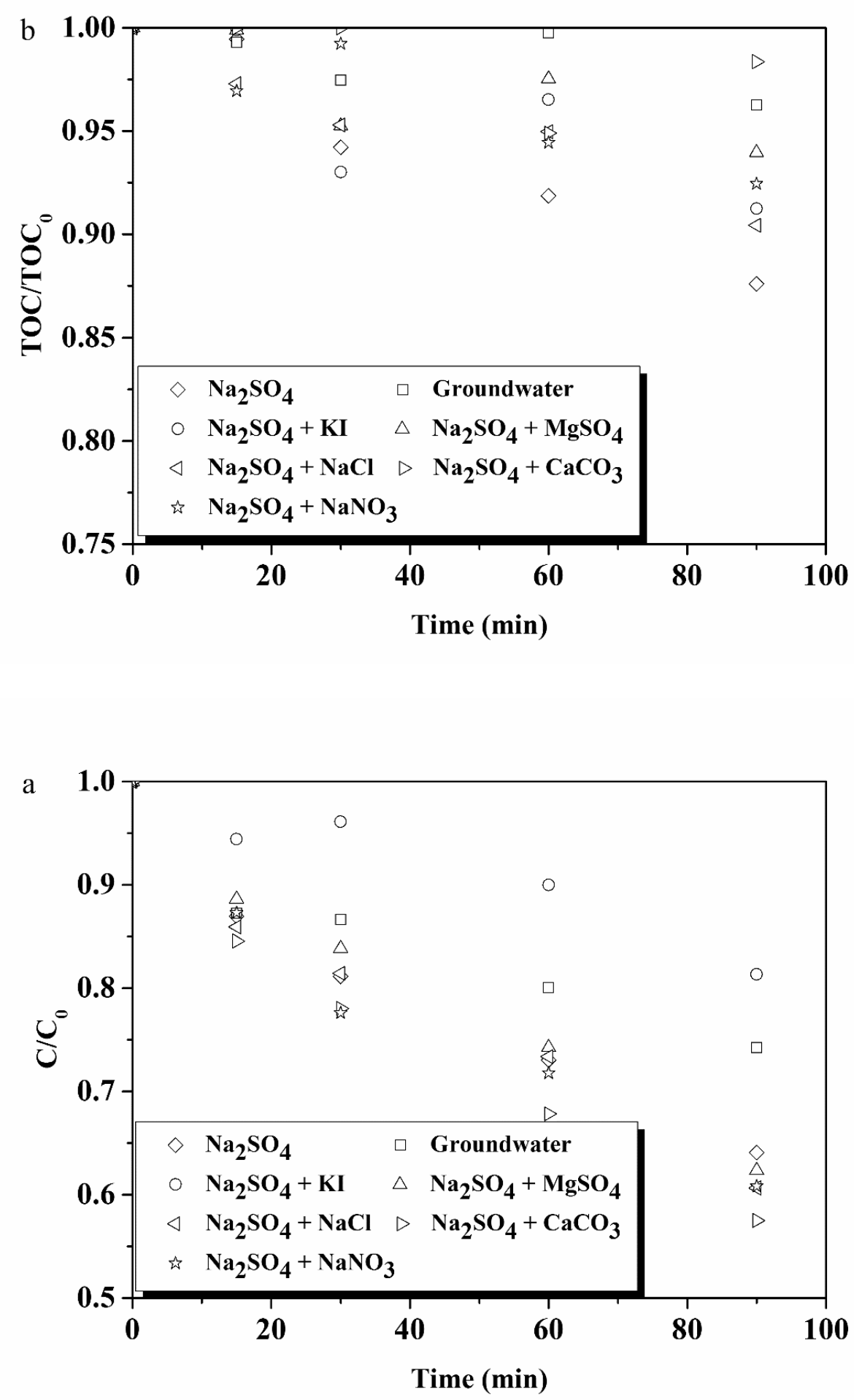

233 Figure 1. Influence of the electrolyte composition on the degradation (a) and 234 mineralization (b) of clopyralid (initial concentration $180 \mathrm{mg} \mathrm{L}^{-1}$ ), $0.1 \mathrm{mM}$ of $\mathrm{Fe}^{2+}, 50$ $235 \mathrm{~mA}$ of current and $0.1 \mathrm{~mL} \mathrm{~min}^{-1}$ of compressed air. 
236 As can be seen in Fig. 1, the removal of the pollutant depended on the composition of the 237 electrolyte used. The influence was mainly visible for the clopyralid degradation, which 238 ranged from $20 \%$ to $40 \%$. However, the mineralization yields presents very similar values 239 in all the cases, about $10 \%$.

240 When the synthetic groundwater was used as electrolyte, average removal efficiencies 241 were obtained, presenting a removal rate of about $0.54 \mathrm{mg} \mathrm{L}^{-1} \mathrm{~min}^{-1}$.

242 In most of the cases, except in the presence of iodide ions, the presence of single trace

243 mineral from the groundwater had a slightly influence on the average degradation rates, 244 presenting the best average removal rate the combination of the $\mathrm{Na}_{2} \mathrm{SO}_{4}$ and $\mathrm{CaCO}_{3}, 0.93$ $245 \mathrm{mg} \mathrm{L}^{-1} \mathrm{~min}^{-1}$. This result indicates that these mineral ions, except the iodide ions, did not 246 interfere on the clopyralid degradation. In Fig. 1a, iodide ions clearly worsened the 247 clopyralid removal process. When the KI was present in the electrolyte, (groundwater 248 electrolyte and $\mathrm{Na}_{2} \mathrm{SO}_{4}+\mathrm{KI}$ electrolyte), only about $20 \%$ of the initial clopyralid was 249 degraded after $90 \mathrm{~min}$.

250 With regard to the mineralization, the best mineralization yield was obtained when using $251 \mathrm{Na}_{2} \mathrm{SO}_{4}$ as the sole supporting electrolyte. Anyway, the low mineralization observed in 252 all the cases during the electrolysis could be explained by the reaction between the 253 hydroxyls radicals and the inorganic compounds contained in the effluent. This reaction 254 involves simple electron transfer of ${ }^{\bullet} \mathrm{OH}$ to form the hydroxide ion with the corresponding 255 change in the oxidation state of the donor (Buxton et al., 1988). Inorganic ions are 256 hydroxyl radical consumers, this statement justify the worse efficiency when mineral salts 257 were used. 
258

259

260

261

262

263

264

265

266

267

268

269

270

271

272

273

274

275

276

277

278

279

In this sense it must be highlighted that, considering the standard potentials of $\mathrm{H}_{2} \mathrm{O}_{2} / \mathrm{H}_{2} \mathrm{O}$ and $\mathrm{I}_{3}{ }^{-} / \mathrm{I}^{-}$redox couple, iodide ions can react with the hydrogen peroxide produced at the cathode surface Eq. (2) interfering with the Fenton reaction.

$\mathrm{H}_{2} \mathrm{O}_{2}+3 \mathrm{I}^{-} \leftrightarrow 2 \mathrm{H}_{2} \mathrm{O}+\mathrm{I}_{3}^{-}$

Another ion interfering the Fenton reaction was chloride ion. According the literature, (Loaiza-Ambuludi et al., 2013) electrogenerated active chlorine can oxidize $\mathrm{Fe}^{2+}$ Eq. (3) or decompose hydrogen peroxide Eq. (4), reducing the production rate of the strong oxidant ${ }^{\bullet} \mathrm{OH}$ by the Fenton's reaction (Beqqal et al., 2017).

$2 \mathrm{Fe}^{2+}+\mathrm{Cl}_{2} \rightarrow 2 \mathrm{Fe}^{3+}+2 \mathrm{Cl}^{-}$

$2 \mathrm{H}_{2} \mathrm{O}_{2}+\mathrm{Cl}_{2} \rightarrow 2 \mathrm{HCl}+\mathrm{H}_{2} \mathrm{O}+\mathrm{O}_{2}$

It should be noted that to allow chloride ions oxidation, the potential of the anode needs to be higher than about $1 \mathrm{~V} / \mathrm{SCE}\left(\mathrm{E}^{0}\left(\mathrm{Cl}_{2} / \mathrm{Cl}^{-}\right)=1.24 \mathrm{~V} / \mathrm{SHE}\right)$ and then the production of chlorine depends on the operating conditions and mainly on the applied current.

\subsection{Effect of the applied cathodic current on $\mathrm{H}_{2} \mathrm{O}_{2}$ production and ferrous regeneration}

\subsubsection{Effect of the current on the $\mathrm{H}_{2} \mathrm{O}_{2}$ production}

Experiments were developed at different currents ranging from 50 to $300 \mathrm{~mA}$. In these experiments, synthetic groundwater was used as supporting electrolyte, during $90 \mathrm{~min}$ at pH 3 and without the addition of Fe(II) and clopyralid to avoid EF reactions. The current 
280 for $\mathrm{H}_{2} \mathrm{O}_{2}$ accumulation depended on some factors like reactor configuration, cathode

281 material and operation conditions. 3D carbonaceous cathodes, such as carbon felt, have

282 demonstrated good properties for $\mathrm{H}_{2} \mathrm{O}_{2}$ formation. Carbon is non-toxic, presents good

283 stability and low catalytic activity of $\mathrm{H}_{2} \mathrm{O}_{2}$ decomposition (Petrucci et al., 2016; Das and

284 Golder, 2017). The obtained results were compared with the same experiments using the

285 typical electrolyte in electrochemistry, $\mathrm{Na}_{2} \mathrm{SO}_{4}(50 \mathrm{mM})$, with the aim to evaluate the 286 influence of the mineral salts used as supporting electrolyte. The production of $\mathrm{H}_{2} \mathrm{O}_{2}$ as

287 function of the electrolysis length and applied current is presented in Fig. 2.

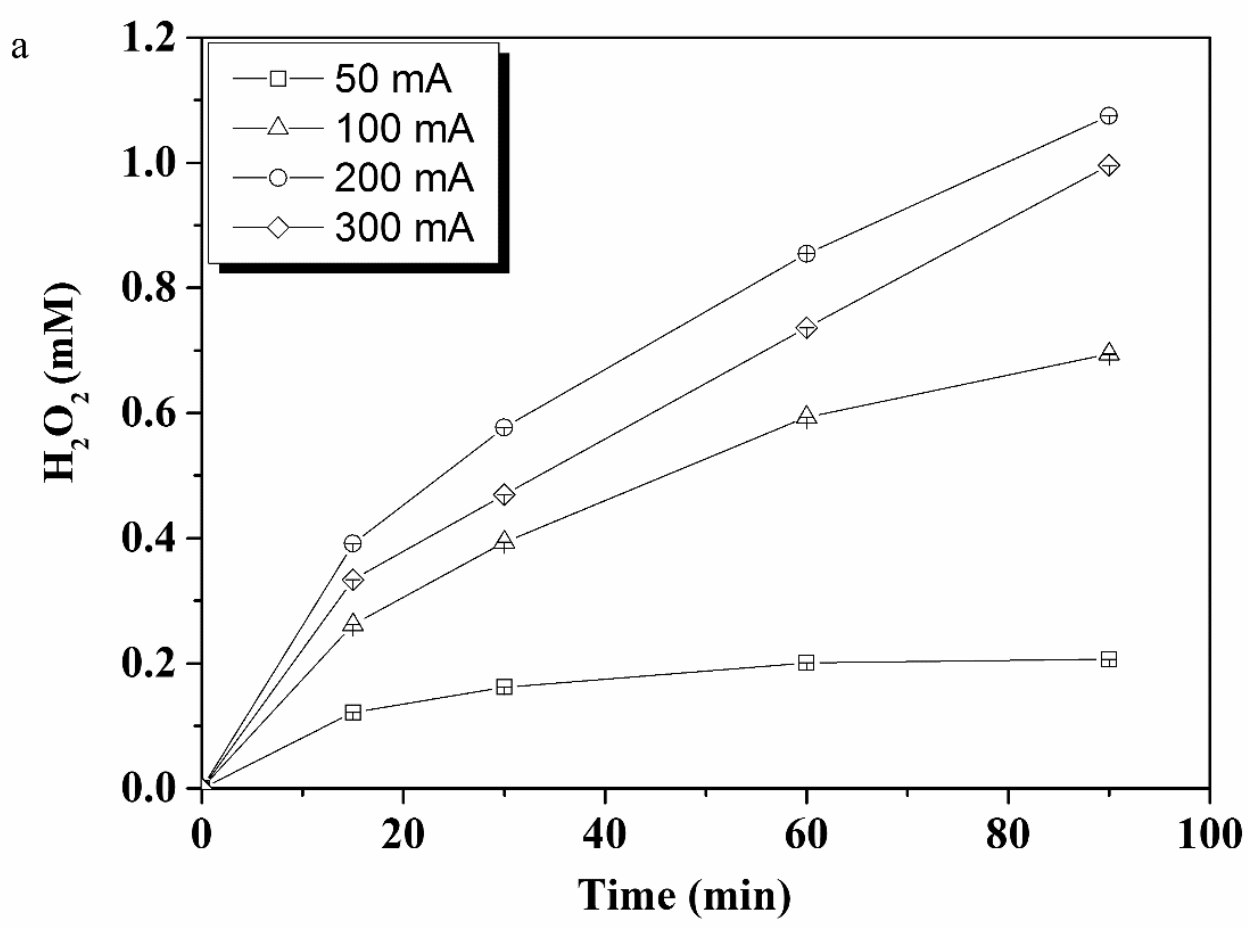




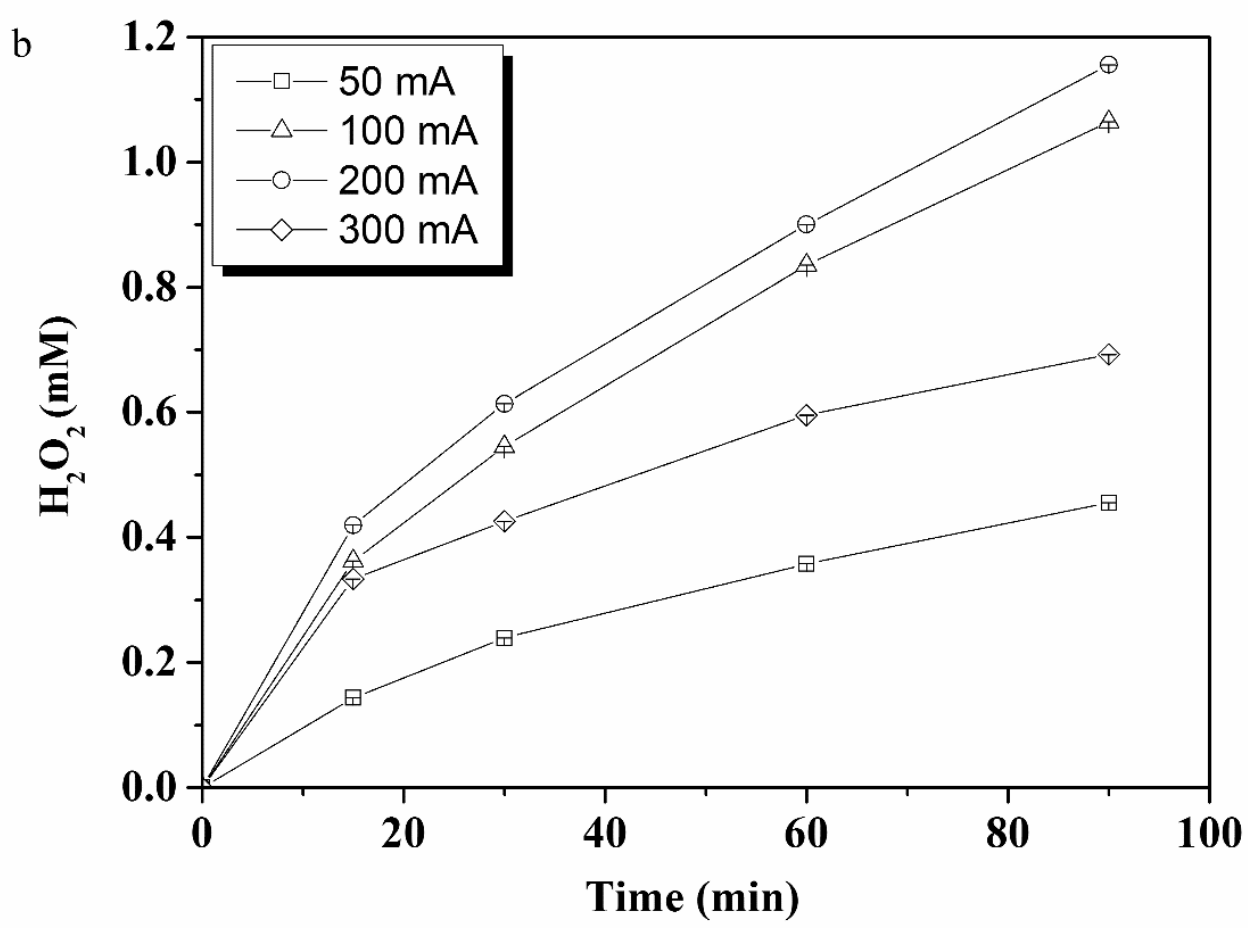

289

290 Figure 2. Effect of the current on the $\mathrm{H}_{2} \mathrm{O}_{2}$ production using (a) groundwater and (b) 50 $291 \mathrm{mM} \mathrm{Na}_{2} \mathrm{SO}_{4}$.

292

293 The $\mathrm{H}_{2} \mathrm{O}_{2}$ production was not linear along the experiment due to the occurrence of 294 parasitic reactions, mainly anodic oxidation of $\mathrm{H}_{2} \mathrm{O}_{2}$ Eq. (4) and cathodic reduction to 295 water Eq. (5) (Pérez et al., 2017; Zhou et al., 2018).

$296 \mathrm{H}_{2} \mathrm{O}_{2} \rightarrow \mathrm{O}_{2}+2 e^{-}+2 \mathrm{H}^{+}$

297

$\mathrm{H}_{2} \mathrm{O}_{2}+2 e^{-}+2 \mathrm{H}^{+} \rightarrow 2 \mathrm{H}_{2} \mathrm{O}$

298 The evolution of the production of $\mathrm{H}_{2} \mathrm{O}_{2}$ during the experiment is directly related with the 299 dissolved oxygen concentration. Usually, dissolved oxygen concentration remains 300 constant at the beginning of the experiment until the polarization of electrodes takes place.

301 After this stage, the concentration of dissolved oxygen in the solution depended on the 302 applied current (Dalle et al., 2017). 
The best $\mathrm{H}_{2} \mathrm{O}_{2}$ productions were achieved when working at $200 \mathrm{~mA}$ with both supporting electrolytes: groundwater and $\mathrm{Na}_{2} \mathrm{SO}_{4}$. However, the concentrations reached with $\mathrm{Na}_{2} \mathrm{SO}_{4}$ as supporting electrolyte were higher compared with groundwater. The maximum concentration of $\mathrm{H}_{2} \mathrm{O}_{2}$ obtained when working at $200 \mathrm{~mA}$ with $\mathrm{Na}_{2} \mathrm{SO}_{4}$ as supporting electrolyte was about $1.16 \mathrm{mM}$; while it was about a $10 \%$ lower using groundwater at the same current, reaching $1.08 \mathrm{mM}$. The difference could be, in part, explained by the reaction of $\mathrm{H}_{2} \mathrm{O}_{2}$ with iodide ions contained in the groundwater can in part explain the lower accumulated concentration.

Working with groundwater as supporting electrolyte, at $50 \mathrm{~mA}$, the production of $\mathrm{H}_{2} \mathrm{O}_{2}$ increased during the first $30 \mathrm{~min}$ and then remained constant, showing the implementation of an equilibrium between the anodic oxidation of $\mathrm{H}_{2} \mathrm{O}_{2}$ Eq. (5) and its cathodic production Eq. (6). This effect was not observed at the other current applied, which indicates that the production process outcompete the anodic oxidation process. Moreover, the amount of $\mathrm{O}_{2}$ produced at the anode, see Eq. (4), increases with the applied current and then favours the production of hydrogen peroxide (Dalle et al., 2017).

$\mathrm{O}_{2}+2 e^{-}+2 \mathrm{H}^{+} \rightarrow 2 \mathrm{H}_{2} \mathrm{O}_{2}$

When operating at higher current densities, the $\mathrm{H}_{2} \mathrm{O}_{2}$ production increased. However, at the highest applied current, $300 \mathrm{~mA}$, the accumulation of $\mathrm{H}_{2} \mathrm{O}_{2}$ did not show a proportional improvement. This behaviour could be explained because the reduction of $\mathrm{O}_{2}$ to form $\mathrm{H}_{2} \mathrm{O}$ becomes preferential (Özcan et al., 2008).

\subsection{Effect of the current on ferrous ions regeneration}

The next step was the study of the ferrous ion regeneration when working with the groundwater medium during $90 \mathrm{~min}$ at $\mathrm{pH} 3$ without the addition of clopyralid. A series 
327 of experiments at different current intensities were carried out with at an initial

328 concentration of $\mathrm{Fe}^{2+}$ of $0.5 \mathrm{mM}$. Fig. (3) shows the evolution of ferrous iron.

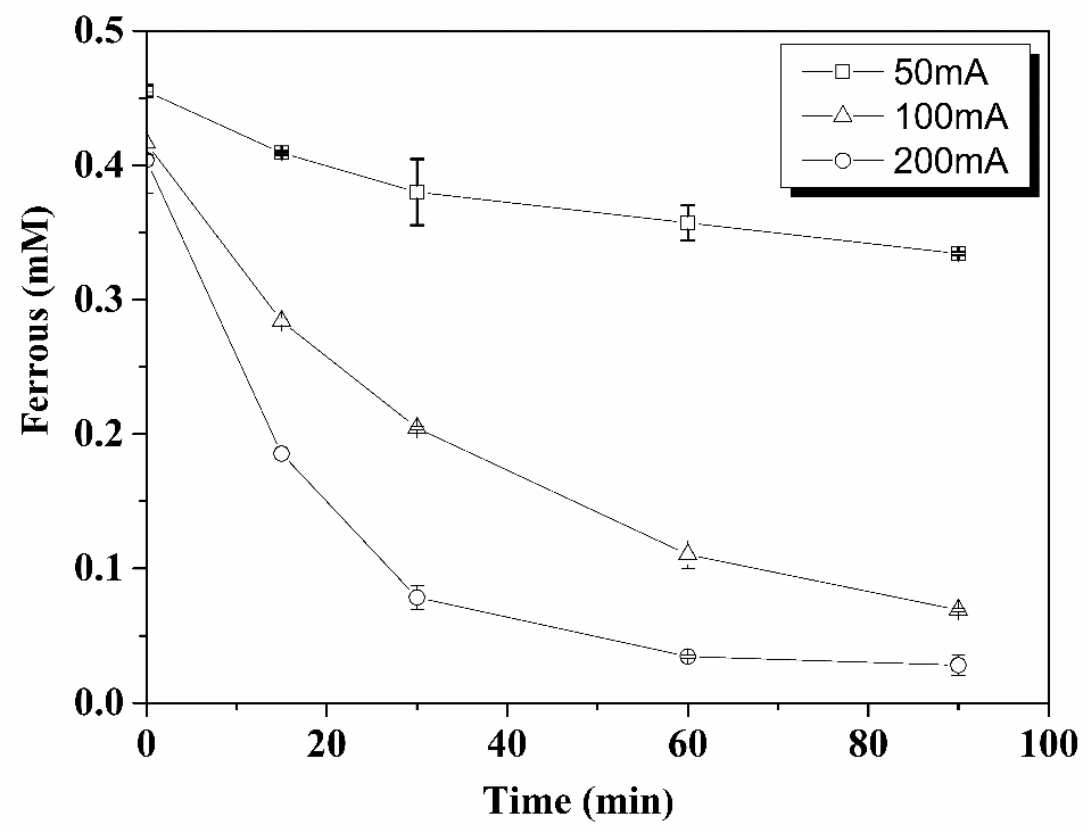

329

330 Figure 3. Effect of the applied current on the ferrous iron concentration.

332 In spite of getting the best $\mathrm{H}_{2} \mathrm{O}_{2}$ production at $200 \mathrm{~mA}$, the worst regeneration of ferrous ions is achieved at the same current. A decrease of ferrous ions concentration about $25 \%$ was observed when the current reached $50 \mathrm{~mA}$. For 100 and $200 \mathrm{~mA}$ a significant 335 decrease in total iron concentration took place after 90 min of electrolysis. The ferrous 336 iron concentration decreased from 0.45 to 0.07 and to $0.03 \mathrm{mM}$ at 100 and $200 \mathrm{~mA}$ 337 respectively.

338 Some of the reasons which explain the bad performance of the highest current intensities 339 in the iron regeneration could be the followings: 
- Water reduction can lead to a local alkalization of the solution caused by hydroxyl anions formation during $\mathrm{H}_{2}$ release and then to the precipitation of iron as $\mathrm{Fe}(\mathrm{OH})_{3}$ (Brillas et al., 2009; Petrucci et al., 2016).

- Iron hydroxide could be adsorbed onto the electrode surface or iron ions could be reduced to metallic iron considering standard potentials for iron redox couples (Aboudalle et al., 2018b).

These phenomena could explain a lower efficiency for the highest current densities.

\subsection{Effect of the initial $\mathrm{Fe}^{2+}$ on the EF experiments}

The initial ferrous ions catalyst concentration is another important parameter in the EF process. Taking into account that the highest production of $\mathrm{H}_{2} \mathrm{O}_{2}$ was obtained at $200 \mathrm{~mA}$, even if the regeneration of the ferrous catalyst was not efficient throughout the electrolysis, the influence of the initial concentration of $\mathrm{FeSO}_{4} \cdot \mathrm{H}_{2} \mathrm{O}$ on the clopyralid degradation was studied with 4 different initial concentrations of $\mathrm{Fe}^{2+}$ ranging from 0.1 to $5 \mathrm{mM}$. As reported in Fig. (4), the initial concentration of ferrous ions influenced the degradation of the clopyralid, fluctuating the removal yield between 18 and $28 \%$. Initial concentrations of 0.1 and $1 \mathrm{mM}$ caused about $25 \%$ of clopyralid degradation. The clopyralid removal slightly increased when the initial concentration of $\mathrm{Fe}^{2+}$ was $2 \mathrm{mM}$ reaching a clopyralid removal percentage of about $28 \%$. Finally, when the concentration of $\mathrm{Fe}^{2+}$ was $5 \mathrm{mM}$ the removal yield decreased to about $18 \%$. This reduction in the clopyralid removal could be explained by the competitive effects between hydroxyl radicals, resulting from the Fenton`s reaction, and the excess of ferrous ions (Panizza and Cerisola, 2009; Aboudalle et al., 2018b), according to Eq. (7). 
365 If ferrous ions concentration had a little influence on the clopyralid degradation, the 366 mineralization of organic compound was not influenced by the catalyst concentration 367 (data not shown). It can be then concluded that the influence of the ferrous ion 368 concentration, within the range studied in this work, does not present a significant effect 369 on the clopyralid removal.

370 This statement is in accordance with other studies, where the initial catalyst concentration 371 does not have a strong influence in the degradation and mineralization of organic 372 pollutants (Loaiza-Ambuludi et al., 2013; Aboudalle et al., 2018b).

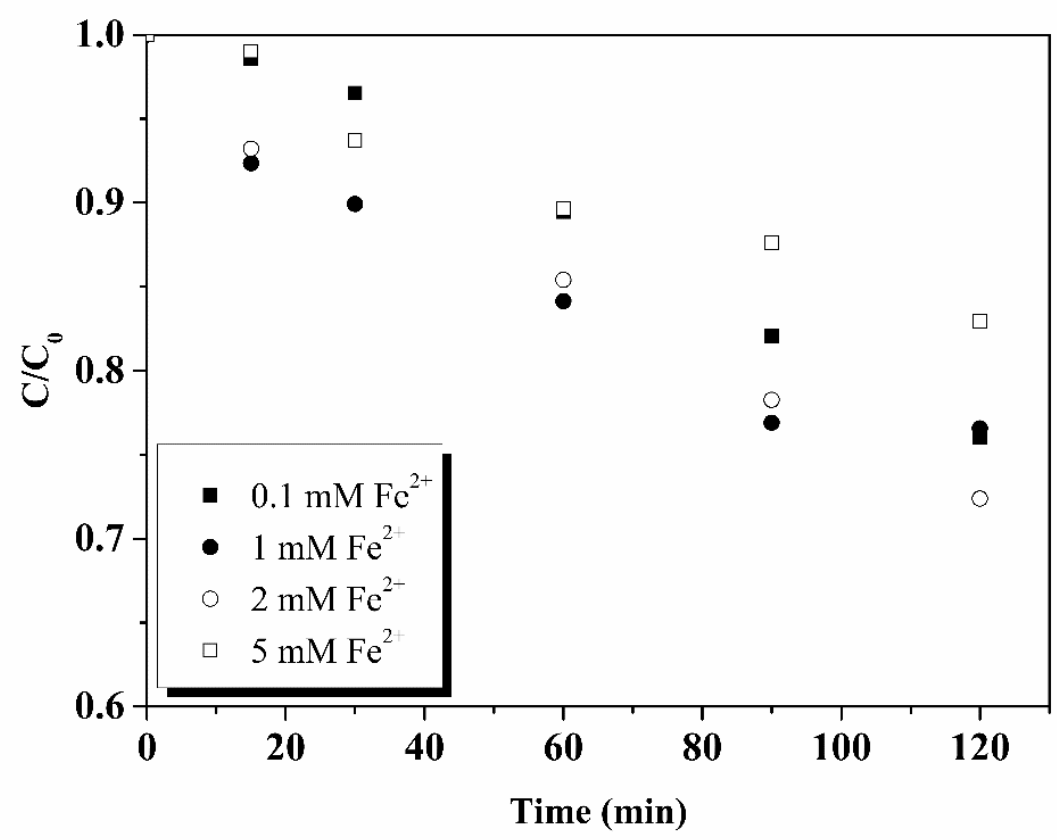

374 Figure 4. Influence of the initial $\mathrm{Fe}^{2+}$ concentration on the clopyralid degradation. Initial 375 clopyralid concentration $180 \mathrm{mg} \mathrm{L}^{-1}$. 


\subsection{Effect of oxygen mass flow rate}

379 One of the main reactions which manage EF is the cathodic reduction of oxygen to 380 generate $\mathrm{H}_{2} \mathrm{O}_{2}$. Oxygen is transferred from the gaseous phase to the aqueous phase, and 381 the dissolved oxygen in the liquid bulk is transferred to the cathode surface, where the 382 reduction takes place. Consequently, it was expected that an increment in the oxygen flow 383 could enhance the mass transfer rate and therefore the subsequent reactions (Do and Yeh, 1996). In order to increase the availability of oxygen in the liquid bulk, the $\mathrm{O}_{2}$ flow rate was increased from 0.1 to $0.3 \mathrm{~L} \mathrm{~min}^{-1}$. During the experiments, the current and the ferrous concentration were kept at $50 \mathrm{~mA}$ and $0.1 \mathrm{mM}$, respectively. As can be seen in Fig. 5,

387 results indicate that an increment in the flow rate from 0.1 to $0.3 \mathrm{~L} \mathrm{~min}^{-1}$ had a slight 388 influence on the removal but not on the mineralization efficiency.

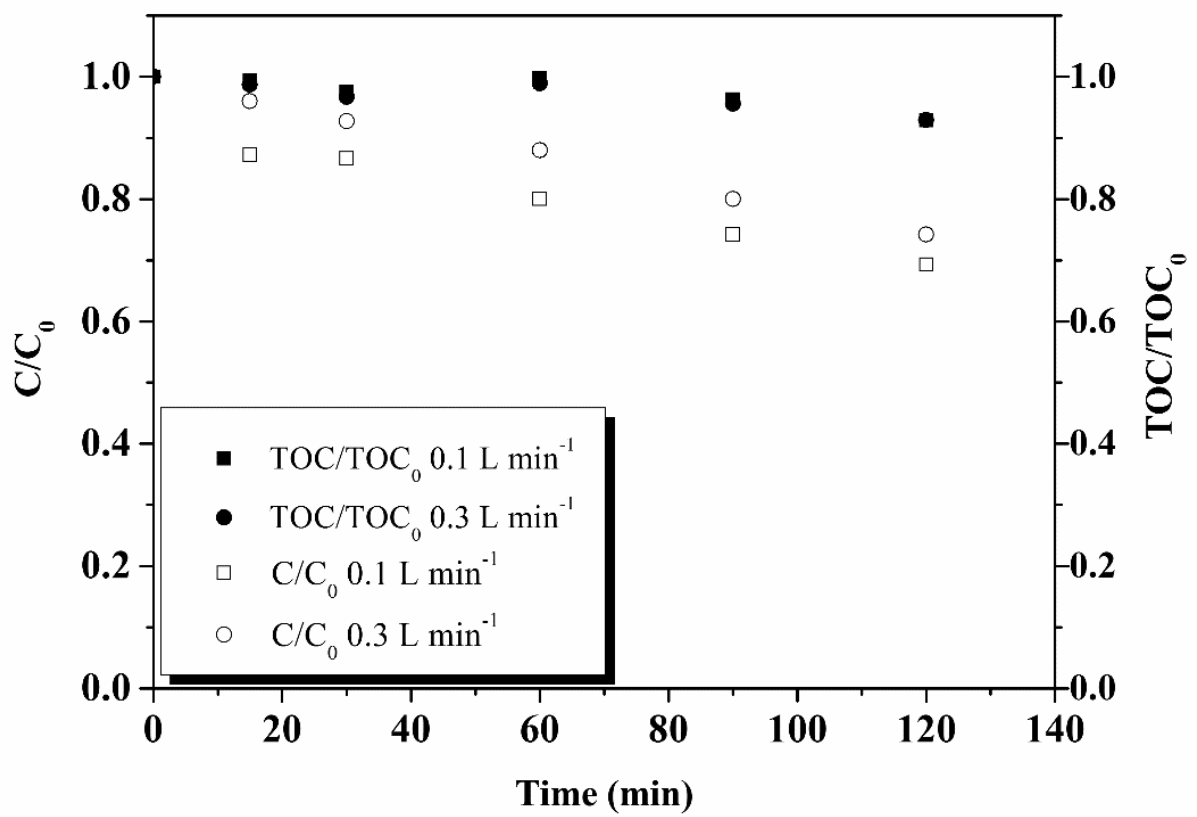


Figure 5. Effect of the oxygen mass flow on the removal efficiency. Clopyralid concentration (full symbols) and TOC concentration (empty symbols).

As can be seen in Fig. 5, the mineralization achieved was almost identical in both cases, whereas the clopyralid removal values were slightly different. Similar results were obtained in research previously reported in the literature (Dalle et al., 2017), where it was demonstrated that an increment from 0.5 to $3 \mathrm{~L} \mathrm{~min}^{-1}$ has not an important influence on the hydrogen peroxide production and hydroxyl radical concentration (Dalle et al., 2017).

This behaviour could be explained by the very similar saturation of oxygen in the liquid bulk obtained in both cases (Dalle et al., 2017). In this sense, the slight enhancement obtained when operating at $0.3 \mathrm{~L} \mathrm{~min}^{-1}$ of oxygen flow rate could be explained by the higher turbulence caused which leads to a higher mass transfer coefficient on the surface of the electrode.

\subsection{Anodic reaction during clopyralid degradation}

In order to study the contribution of a direct oxidation and/or reduction of the clopyralid at the electrode surfaces during the EF process, the electrochemical behaviour of the target pollutant was also investigated. For this purpose, current potential curves were plotted and electrolysis with and without tert-butanol were implemented. Tert-butanol is used here as scavenger which reacts with hydroxyl radicals, generating inert 410 intermediates. These inert compounds cause the termination of the radical chain reaction 411 (Ma and Graham, 2000). The current potential curves, obtained by cyclic voltammetry, were carried out with a vitreous carbon electrode $\left(S=7.07 \mathrm{~mm}^{2}\right)$ as a working electrode when the curves were plotted in reduction, a platinum electrode in oxidation $(\mathrm{S}=3.14$ 
$\left.414 \mathrm{~mm}^{2}\right)$, a Pt counter electrode and SCE as reference electrode $\left(\mathrm{r}=100 \mathrm{mV} \mathrm{s}^{-1}\right)$. These 415 measurements were carried out under nitrogen atmosphere, at room temperature, $\mathrm{pH} 3$ 416 and at a clopyralid concentration of $180 \mathrm{mg} \mathrm{L}^{-1}$. In order to isolate the behaviour of the 417 clopyralid two current potential curves were carried out, one of them with groundwater 418 as supporting electrolyte, and the other one with groundwater and clopyralid. The 419 obtained results are presented in Fig. SM-1 and did not show any clopyralid reaction at 420 the electrodes surface.

421 The current-potential curves did not show any signal in reduction with vitreous carbon

422 electrode (data not shown). With a platinum working electrode, a reversible signal 423 appeared in both curves, due to the oxidation of one of the ions in the groundwater. The 424 peak detected on the platinum anode took places at $+0.54 \mathrm{~V}$ and could be related with the oxidation of $\mathrm{I}^{-}$into $\mathrm{I}_{3}{ }^{-}$. A signal was also observed around $+1 \mathrm{~V}$ and can be attributed to the oxidation of chloride ions. In this case, the formation of chlorine during the electrolysis can influence the production of hydroxyl radicals.

Besides this analysis, the degradation of clopyralid on the anodic surface was studied through a simple electrolysis and electrolysis but in the presence of tert-butanol. These electrolyses, as well as an EF experiment in view of comparison, were made in the same operating conditions, applying $50 \mathrm{~mA}$ of current during $120 \mathrm{~min}$. Both electrolyses tests achieved $10 \%$ of clopyralid removal, whereas EF led to $30 \%$ removal. These results confirm again that the electrooxidation of clopyralid was negligible.

3.7. Biodegradability of the electrolyzed soil washing effluents

Due to the low mineralization yield, a longer EF treatment was considered in order to improve the mineralization yield and the biodegradability of the wastewater after the 
treatment. Two long electrolysis experiments were implemented at 50 and $200 \mathrm{~mA}$ and

440 the generation of carboxylic acid was followed. In the literature, the ratio $\mathrm{BOD}_{5} / \mathrm{COD}$ is

441 usually employed to analyse the biodegradability of water samples (Zaghdoudi et al.,

442 2017). If the ratio exceeds 0.4 , the sample can be considered biodegradable (Carboneras

443 et al., 2018). The obtained results are presented in Figs. 6 and 7 respectively. Experiments

444 were carried out by adding $1 \mathrm{mM}$ of ferrous ions and lasted $8 \mathrm{~h}$.

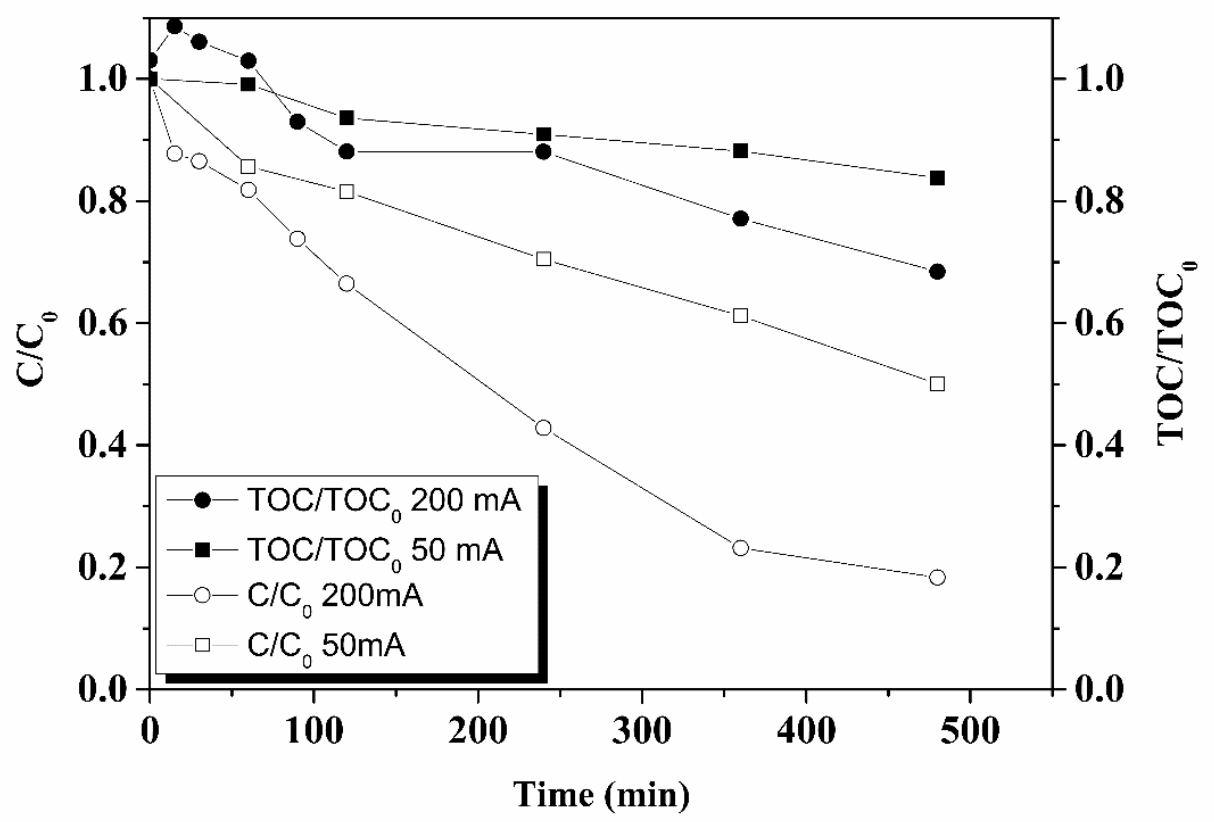

445

Figure 6. Time-courses of clopyralid degradation and its mineralization during $\mathrm{EF}$ at 50 and $200 \mathrm{~mA}$.

A can be seen in Fig. 6, when operating at a current of $200 \mathrm{~mA}$, a higher mineralization efficiency and a higher degradation of clopyralid was obtained, reaching 30 and $80 \%$ respectively. These results could be related to the higher production of $\mathrm{H}_{2} \mathrm{O}_{2}$ when the system was operated at $200 \mathrm{~mA}$. However, in spite of getting a good removal of clopyralid, the mineralization yield reached only around $30 \%$. This result can be 
explained by the formation of a too low concentration of $\bullet \mathrm{OH}$ linked to a non-efficient

455 regeneration of ferrous ions to completely mineralize clopyralid (Aboudalle et al., 2018a). The IC analysis showed the formation of 3 carboxylic acids: acetic, formic and oxalic acids. When clopyralid was removed, these three carboxylic acids appeared, increasing their concentration during the experiments, reaching the highest concentrations at the end of the experiment. Fig. 7 shows the acids concentration along the experiments.

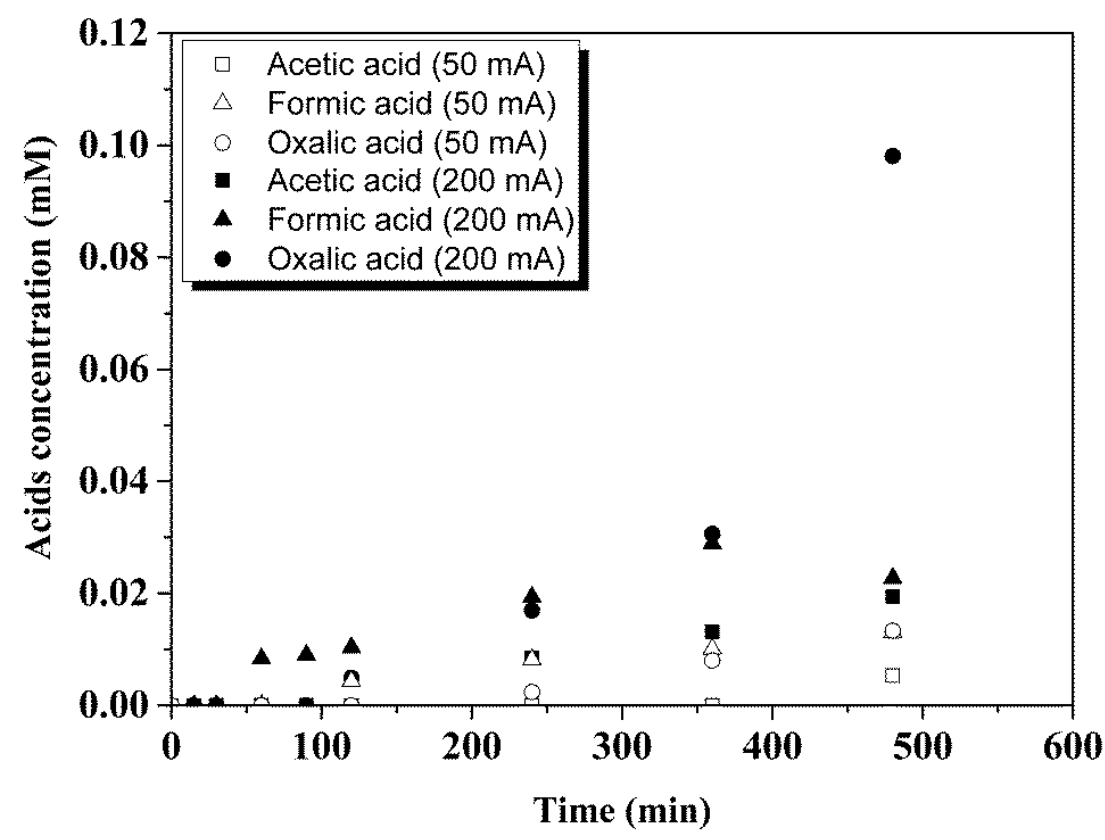

Figure 7. Evolution of carboxylic acid concentrations along EF reactions at $50 \mathrm{~mA}$ (empty symbols) and at $200 \mathrm{~mA}$ (full symbols).

With regard to the cumulative acids production, the electrolysis carried out at $200 \mathrm{~mA}$ led to the highest concentration, $0.10 \mathrm{mM}$ for oxalic acid, a concentration about ten times higher than those obtained after the electrolysis at $50 \mathrm{~mA}$.

During the electrolysis at $200 \mathrm{~mA}$, the rate of carboxylic acids, especially oxalic acid, seemed to significantly increase from $360 \mathrm{~min}$. It can be then expected that the biodegradability of the effluent can be improved with the significant increase in the 
production rate of such carboxylic acids. In order to ratify this hypothesis, the $\mathrm{BOD}_{5} / \mathrm{COD}$ ratios obtained after both experiments, carried out at 50 and $200 \mathrm{~mA}$ of current density, were determined. Table SM-2 presents the initial and final $\mathrm{BOD}_{5} / \mathrm{COD}$ ratios obtained in the experiments carried out with $1 \mathrm{mM}$ of ferrous ions and groundwater as a supporting electrolyte at 50 and $200 \mathrm{~mA}$.

The initial solution of clopyralid was not considered biodegradable because of its $\mathrm{BOD}_{5} / \mathrm{COD}$ ratio below 0.4 . However, the initial value of this ratio, 0.33 , means that some biodegradable compounds were present in the commercial clopyralid formulation (Fontmorin et al., 2014).

After $480 \mathrm{~min}$ of electrolysis at $200 \mathrm{~mA}$ the solution became biodegradable reaching $\mathrm{BOD}_{5} / \mathrm{COD}$ ratios of 0.48 and 0.39 when applying 200 and $50 \mathrm{~mA}$ respectively (Table SM-2). This behaviour could be explained by the production of carboxylic acids \{Fernandez, 2008, Evaluation of carbon degradation during co-composting of exhausted grape marc with different biowastes . This improvement of the biodegradability can be explained by the significant generation of carboxylic acids and especially oxalic acid that can be easily metabolized by microorganisms (Fernández et al., 2008). Monitoring the evolution of carboxylic acids during the electrolysis could be then an interesting diagnostic tool for the estimation of biodegradability and could be easily inserted into the process. Regarding the electrolysis at $50 \mathrm{~mA}$, biodegradability of the electrolyzed solution was nearly similar to the initial biodegradability, which can also be explained by the low mineralization of the organic compounds and then the presence of by-products structurally close to clopyralid (Mansour et al., 2012). 


\section{CONCLUSIONS}

496

497

498

499

500

501

502

503

504

505

506

507

508

509

510

511

512

513

514

515

516

517

518

519

From this study, several conclusions can be extracted. Voltammetric study showed that clopyralid was not electroactive and then was not degraded at the electrode surface by a heterogeneous electron transfer. At a current of $200 \mathrm{~mA}, 80 \%$ of clopyralid was degraded and mineralization yield reached $30 \%$, improving the biodegradability ratio $\mathrm{BOD}_{5} / \mathrm{COD}$ from 0.33 to 0.48 in $480 \mathrm{~min}$. The evolution of the carboxylic acids was studied and the results seemed to show that the improvement of biodegradability can be linked to a significant increase of the carboxylic acids production rate and more especially oxalic acid. The EF process can be carried out using groundwater as sustainable supporting electrolyte. It allows the use of a natural resource, groundwater, avoiding the addition of synthetic electrolytes and the increase of the salinity of the natural water bodies receiving these effluents. The groundwater had a significant influence in the EF efficiency, reducing the $\mathrm{H}_{2} \mathrm{O}_{2}$ production and, therefore, the efficiency of the EF process. The mineral salt that presented the highest impact on the process was KI. In the studied operating conditions, neither the initial catalyst concentration nor the oxygen flow rate had a significant influence in the EF process. Because of that, an EF pre-treatment can be used to improve the biodegradability of polluted soil washing effluent using groundwater as a supporting electrolyte.

\section{Acknowledgements}

Authors wish to express their gratitude to the financial support from the Spanish Ministry of Economy, Industry and Competitiveness and European Union through project CTM2016-76197-R (AEI/FEDER, UE) and CYTEMA -Campus Científico y Tecnológico de la Energía y el Medioambiente- for the pre-doc CYTEMA-Net mobility grant of María Belén Carboneras. 
522 Aboudalle, A., Djelal, H., Fourcade, F., Domergue, L., Assadi, A.A., Lendormi, T., Taha, S., Amrane, 523 A., 2018a. Metronidazole removal by means of a combined system coupling an electro-Fenton 524 process and a conventional biological treatment: By-products monitoring and performance 525 enhancement. J. Hazard. Mater. 359, 85-95.

526 Aboudalle, A., Fourcade, F., Assadi, A.A., Domergue, L., Djelal, H., Lendormi, T., Taha, S., Amrane, 527 A., 2018b. Reactive oxygen and iron species monitoring to investigate the electro-Fenton 528 performances. Impact of the electrochemical process on the biodegradability of metronidazole 529 and its by-products. Chemosphere 199, 486-494.

530 AFNOR, A.F.d.N., 1982. Essais des eaux: dosage du fer : méthode spectrométrique à la 531 phénanthroline - 1,10 : norme française homologuée NF T90-017., Paris, France.

532 Aydin, M.E., Aydin, S., Beduk, F., Ulvi, A., Bahadir, M., 2018. Accumulation of Micropollutants in 533 Aqueous Media and Sediment, A Risk Assessment for Konya Main Drainage Channel, Turkey. 534 International Conference on Applied Human Factors and Ergonomics. Springer, pp. 286-295.

535 Barrera-Díaz, C., Cañizares, P., Fernández, F., Natividad, R., Rodrigo, M., 2014. Electrochemical 536 advanced oxidation processes: an overview of the current applications to actual industrial 537 effluents. J. Mex. Chem. Soc. 58, 256-275.

538 Belen Carboneras, M., Villasenor, J., Jesus Fernandez-Morales, F., Andres Rodrigo, M., Canizares, 539 P., 2018. Biological treatment of wastewater polluted with an oxyfluorfen-based commercial 540 herbicide. Chemosphere 213, 244-251.

541 Beqqal, N., Yahya, M.S., Karbane, M., Guessous, A., El Kacemi, K., 2017. Kinetic study of the 542 degradation/mineralization of aqueous solutions contaminated with Rosuvastatin drug by 543 Electro-Fenton: Influence of experimental parameters. J. Mat. Environ. Sci. 8, 4399-4407.

544 Bortleson, G.C., Davis, D., 1997. Pesticides in selected small streams in the Puget Sound Basin, 545 1987-1995. US Geological Survey.

546 Bouaziz, I., Hamza, M., Sellami, A., Abdelhédi, R., Savall, A., Serrano, K.G., 2017. New hybrid process 547 combining adsorption on sawdust and electroxidation using a BDD anode for the treatment of 548 dilute wastewater. Sep. Purif. Technol. 175, 1-8.

549 Brillas, E., Sirés, I., Oturan, M.A., 2009. Electro-Fenton process and related electrochemical 550 technologies based on Fenton's reaction chemistry. Chem. Rev. 109, 6570-6631.

551 Buxton, G.V., Greenstock, C.L., Helman, W.P., Ross, A.B., 1988. Critical review of rate constants for 552 reactions of hydrated electrons, hydrogen atoms and hydroxyl radicals $(\cdot \mathrm{OH} / \cdot \mathrm{O}-$ in aqueous 553 solution. J. Phys. Chem. Ref. Data 17, 513-886.

554 Cano-Sancho, G., Ploteau, S., Matta, K., Adoamnei, E., Louis, G.B., Mendiola, J., Darai, E., Squifflet, 555 J., Le Bizec, B., Antignac, J.-P., 2019. Human epidemiological evidence about the associations 556 between exposure to organochlorine chemicals and endometriosis: Systematic review and 557 meta-analysis. Environ. Int. 123, 209-223.

558 Carboneras, M.B., Cañizares, P., Rodrigo, M.A., Villaseñor, J., Fernandez-Morales, F.J., 2018. 559 Improving biodegradability of soil washing effluents using anodic oxidation. Bioresour. Technol. $560 \quad 252,1-6$.

561 Chair, K., Bedoui, A., Bensalah, N., Fernández-Morales, F.J., Sáez, C., Cañizares, P., Rodrigo, M.A., 562 2017a. Combining bioadsorption and photoelectrochemical oxidation for the treatment of soil563 washing effluents polluted with herbicide 2,4-D. J. Chem. Technol. Biotechnol. 92, 83-89.

564 Chair, K., Bedoui, A., Bensalah, N., Sáez, C., Fernández-Morales, F.J., Cotillas, S., Cañizares, P., 565 Rodrigo, M.A., 2017b. Treatment of Soil-Washing Effluents Polluted with Herbicide Oxyfluorfen 566 by Combined Biosorption-Electrolysis. Ind. Eng. Chem. Res. 56, 1903-1910.

567 Chaplin, B.P., 2014. Critical review of electrochemical advanced oxidation processes for water 568 treatment applications. Environ. Sci.: Processes Impacts 16, 1182-1203. 
569 Comninellis, C., Kapalka, A., Malato, S., Parsons, S.A., Poulios, I., Mantzavinos, D., 2008. Advanced 570 oxidation processes for water treatment: advances and trends for R\&D J. Chem. Technol. 571 Biotechnol. 83, 769-776.

572 Dalle, A.A., Domergue, L., Fourcade, F., Assadi, A.A., Djelal, H., Lendormi, T., Soutrel, I., Taha, S., 573 Amrane, A., 2017. Efficiency of DMSO as hydroxyl radical probe in an Electrochemical Advanced

574 Oxidation Process- Reactive oxygen species monitoring and impact of the current density. 575 Electrochim. Acta 246, 1-8.

576 Das, R.K., Golder, A.K., 2017. Impact of supporting electrolytes on the stability of TiO 2-Ti counter 577 electrode during H 2 O 2 electrogeneration. Surf. Eng. Appl. Electrochem. 53, 570-579.

578 De Lucas, A., Rodriguez, L., Villasenor, J., Fernandez, F.J., 2007. Influence of industrial discharges 579 on the performance and population of a biological nutrient removal process. Biochem. Eng. J. 580 34, 51-61.

581 Diagne, M., Oturan, N., Oturan, M.A., 2007. Removal of methyl parathion from water by 582 electrochemically generated Fenton's reagent. Chemosphere 66, 841-848.

583 Do, J.-S., Yeh, W.-C., 1996. Paired electrooxidative degradation of phenol with in situ 584 electrogenerated hydrogen peroxide and hypochlorite. J. Appl. Electrochem. 26, 673-678.

585 Eisenberg, G., 1943. Colorimetric determination of hydrogen peroxide. Ind. Eng. Chem., Anal. Ed. $586 \quad 15,327-328$.

587 Feng, L., Oturan, N., Van Hullebusch, E.D., Esposito, G., Oturan, M.A., 2014. Degradation of anti588 inflammatory drug ketoprofen by electro-oxidation: comparison of electro-Fenton and anodic 589 oxidation processes. Environ. Sci. Pollut. Res. 21, 8406-8416.

590 Fernández, F.J., Sánchez-Arias, V., Villaseñor, J., Rodríguez, L., 2008. Evaluation of carbon 591 degradation during co-composting of exhausted grape marc with different biowastes. 592 Chemosphere 73, 670-677.

593 Fontmorin, J.-M., Siguié, J., Fourcade, F., Geneste, F., Floner, D., Soutrel, I., Amrane, A., 2014. 594 Combined electrochemical treatment/biological process for the removal of a commercial 595 herbicide solution, U46D ${ }^{\circledR}$. Sep. Purif. Technol. 132, 704-711.

596 Ganzenko, O., Huguenot, D., Van Hullebusch, E.D., Esposito, G., Oturan, M.A., 2014. 597 Electrochemical advanced oxidation and biological processes for wastewater treatment: a 598 review of the combined approaches. Environ. Sci. Pollut. Res. 21, 8493-8524.

599 Garcia-Becerra, F.Y., Ortiz, I., 2018. Biodegradation of Emerging Organic Micropollutants in 600 Nonconventional Biological Wastewater Treatment: A Critical Review. Environ. Eng. Sci. 35, 601 1012-1036.

602 Gaur, N., Narasimhulu, K., PydiSetty, Y., 2018. Recent advances in the bio-remediation of persistent 603 organic pollutants and its effect on environment. J. Cleaner Prod. 198, 1602-1631.

604 Glaze, W.H., 1987. Drinking-water treatment with ozone. Environ. Sci. Technol. 21, 224-230.

605 Huang, C., Dong, C., Tang, Z., 1993. Advanced chemical oxidation: its present role and potential 606 future in hazardous waste treatment. Waste Manag. 13, 361-377.

607 Kumar, S., Kaushik, G., Dar, M.A., Nimesh, S., Lopez-Chuken, U.J., Villarreal-Chiu, J.F., 2018. 608 Microbial Degradation of Organophosphate Pesticides: A Review. Pedosphere 28, 190-208.

609 Liang, P., Rivallin, M., Cerneaux, S., Lacour, S., Petit, E., Cretin, M., 2016. Coupling cathodic Electro610 Fenton reaction to membrane filtration for $\mathrm{AO7}$ dye degradation: A successful feasibility study. 611 J. Membr. Sci. 510, 182-190.

612 Liu, G., Li, L., Huang, X., Zheng, S., Xu, X., Liu, Z., Zhang, Y., Wang, J., Lin, H., Xu, D., 2018. Adsorption 613 and removal of organophosphorus pesticides from environmental water and soil samples by 614 using magnetic multi-walled carbon nanotubes@ organic framework ZIF-8. J. Mater. Sci., 1-12.

615 Loaiza-Ambuludi, S., Panizza, M., Oturan, N., Özcan, A., Oturan, M.A., 2013. Electro-Fenton 616 degradation of anti-inflammatory drug ibuprofen in hydroorganic medium. J. Electroanal. Chem. 617 702, 31-36.

$618 \mathrm{Ma}$, J., Graham, N.J., 2000. Degradation of atrazine by manganese-catalysed ozonation-influence 619 of radical scavengers. Water Res. 34, 3822-3828. 
620 Mansour, D., Fourcade, F., Bellakhal, N., Dachraoui, M., Hauchard, D., Amrane, A., 2012. 621 Biodegradability improvement of sulfamethazine solutions by means of an electro-Fenton 622 process. Water, Air, Soil Pollut. 223, 2023-2034.

623 Minerales, E., 1985. Calidad y contaminación de las aguas 475 subterráneas en España: informe de 624 síntesis. Instituto Geológico y Minero de España 476, 477.

625 Moreira, F.C., Boaventura, R.A., Brillas, E., Vilar, V.J., 2017. Electrochemical advanced oxidation 626 processes: a review on their application to synthetic and real wastewaters. Appl. Catal., B 202, $627 \quad 217-261$.

628 Oller, I., Malato, S., Sánchez-Pérez, J., 2011. Combination of advanced oxidation processes and 629 biological treatments for wastewater decontamination-a review. Sci. Total Environ. 409, 41416304166.

631 Oturan, M.A., Pimentel, M., Oturan, N., Sirés, I., 2008. Reaction sequence for the mineralization of 632 the short-chain carboxylic acids usually formed upon cleavage of aromatics during 633 electrochemical Fenton treatment. Electrochim. Acta 54, 173-182.

634 Panizza, M., Cerisola, G., 2009. Electro-Fenton degradation of synthetic dyes. Water Res. 43, 339635344.

636 Petrucci, E., Da Pozzo, A., Di Palma, L., 2016. On the ability to electrogenerate hydrogen peroxide 637 and to regenerate ferrous ions of three selected carbon-based cathodes for electro-Fenton 638 processes. Chem. Eng. J. 283, 750-758.

639 Pérez, J.F., Sáez, C., Llanos, J., Cañizares, P., López, C., Rodrigo, M.A., 2017. Improving the efficiency 640 of carbon cloth for the electrogeneration of $\mathrm{H} 2 \mathrm{O} 2$ : role of polytetrafluoroethylene and carbon 641 black loading. Ind. Eng. Chem. Res. 56, 12588-12595.

642 Pimentel, D., Levitan, L., 1986. Pesticides: amounts applied and amounts reaching pests. Bioscience 643 36, 86-91.

644 Pérez, G., Fernández-Alba, A., Urtiaga, A., Ortiz, I., 2010. Electro-oxidation of reverse osmosis 645 concentrates generated in tertiary water treatment. Water Res. 44, 2763-2772.

646 Sirés, I., Brillas, E., Oturan, M.A., Rodrigo, M.A., Panizza, M., 2014. Electrochemical advanced 647 oxidation processes: today and tomorrow. A review. Environ. Sci. Pollut. Res. 21, 8336-8367.

648 Tilman, D., Cassman, K.G., Matson, P.A., Naylor, R., Polasky, S., 2002. Agricultural sustainability and 649 intensive production practices. Nature 418, 671.

650 Urtiaga, A., Pérez, G., Ibáñez, R., Ortiz, I., 2013. Removal of pharmaceuticals from a WWTP 651 secondary effluent by ultrafiltration/reverse osmosis followed by electrochemical oxidation of 652 the RO concentrate. Desalination 331, 26-34.

653 Verma, J.P., Jaiswal, D.K., Sagar, R., 2014. Pesticide relevance and their microbial degradation: a654 state-of-art. Rev. Environ. Sci. Bio/Technol. 13, 429-466.

655 Verma, P., Verma, P., Sagar, R., 2013. Variations in N mineralization and herbaceous species 656 diversity due to sites, seasons, and $\mathrm{N}$ treatments in a seasonally dry tropical environment of 657 India. For. Ecol. Manage. 297, 15-26.

658 Wang, L., Yao, Y., Zhang, Z., Sun, L., Lu, W., Chen, W., Chen, H., 2014. Activated carbon fibers as an 659 excellent partner of Fenton catalyst for dyes decolorization by combination of adsorption and 660 oxidation. Chem. Eng. J. 251, 348-354.

661 Xie, H., Wang, X., Chen, J., Li, X., Jia, G., Zou, Y., Zhang, Y., Cui, Y., 2019. Occurrence, distribution 662 and ecological risks of antibiotics and pesticides in coastal waters around Liaodong Peninsula, 663 China. Sci. Total Environ. 656, 946-951.

664 Zaghdoudi, M., Fourcade, F., Soutrel, I., Floner, D., Amrane, A., Maghraoui-Meherzi, H., Geneste, 665 F., 2017. Direct and indirect electrochemical reduction prior to a biological treatment for 666 dimetridazole removal. J. Hazard. Mater. 335, 10-17.

667 Zhou, W., Gao, J., Ding, Y., Zhao, H., Meng, X., Wang, Y., Kou, K., Xu, Y., Wu, S., Qin, Y., 2018. Drastic 668 enhancement of $\mathrm{H} 2 \mathrm{O} 2$ electro-generation by pulsed current for ibuprofen degradation: Strategy 669 based on decoupling study on H2O2 decomposition pathways. Chem. Eng. J. 338, 709-718. 
670 Özcan, A., Oturan, M.A., Oturan, N., Şahin, Y., 2009. Removal of Acid Orange 7 from water by 671 electrochemically generated Fenton's reagent. J. Hazard. Mater. 163, 1213-1220.

672 Özcan, A., Şahin, Y., Koparal, A.S., Oturan, M.A., 2008. Carbon sponge as a new cathode material 673 for the electro-Fenton process: comparison with carbon felt cathode and application to 674 degradation of synthetic dye basic blue 3 in aqueous medium. J. Electroanal. Chem. 616, 71-78.

675

676 